\title{
University Collaboration in Delivering Applied Health and Nursing Services Research Training
}

\section{La collaboration universitaire dans l'offre de programmes de formation dans le domaine de la recherche appliquée en services de santé et de soins infirmiers}

by ALBA DiCENSO, RN, PHD

Professor, School of Nursing E Department of Clinical Epidemiology E Biostatistics McMaster University

Canadian Health Services Research Foundation/Canadian Institutes of Health Research Chair in Advanced Practice Nursing

Director, Ontario Training Centre in Health Services and Policy Research Hamilton, ON

DANIELLE D'AMOUR, RN, PHD

Professeure agrégée

Faculté des sciences infirmières, GRIS

Université de Montréal

Directrice, Le Centre FERASI

Montréal, QC

ANNE J. KEARNEY, RN, PHD

Assistant Professor, School of Nursing and Faculty of Medicine, Memorial University Principal, Atlantic Regional Training Centre

St. John's, NL 
University Collaboration in Delivering Applied Health and Nursing Services Research Training

SAM SHEPS, MD, MSC, FRCP

Professor and Director, Western Regional Training Centre for Health Services Research

The School of Population and Public Health

Faculty of Medicine, University of British Columbia

Vancouver, BC

\begin{abstract}
In 2001-2002, the Canadian Health Services Research Foundation (CHSRF) and the Canadian Institutes of Health Research (CIHR) committed 10 years of funding for the creation and implementation of three Regional Training Centres to build capacity in health services and policy research in the Atlantic, Ontario and Western regions of Canada and one training centre in Quebec to focus on the development of nursing services researchers. Each RTC comprises several universities that collaborate to deliver the graduate training. The authors of this paper describe the consortium-related features of the RTCs, including approval processes, formal agreements, governance, communication, students, curriculum, administration and use of educational technology. The discussion outlines the benefits and challenges of university collaboration for participating students, faculty and universities and summarizes lessons learned.
\end{abstract}

\title{
Résumé
}

En 2001-2002, la Fondation canadienne de la recherche sur les services de santé (FCRSS) et les Instituts de recherche en santé du Canada (IRSC) ont alloué 10 ans de financement pour la création et la mise sur pied de quatre Centres régionaux de formation (CRF) - en Ontario, au Québec et dans les régions de l'Atlantique et de l'Ouest du Canada - afin d'accroître la capacité dans le domaine de la recherche en services et en politiques de santé et de favoriser la formation de chercheurs en services infirmiers. Chaque CRF comprend plusieurs universités qui collaborent pour offrir le programme détudes supérieures. Les auteurs de cet article décrivent les caractéristiques des CRF qui sapparentent à celles des consortiums, y compris les processus d'approbation, les ententes officielles, la gouvernance, la communication, les étudiants, les programmes d'études, l'administration et l'emploi de la technologie d'enseignement. L'article présente les avantages et les défis de la collaboration universitaire pour les étudiants, le corps professoral et les universités et résume les leçons apprises.

\section{Key messages}

- University consortia have been successfully developed across Canada to prepare 
graduate-level applied health and nursing services researchers.

- While inter-university collaboration entails considerable time and resources, the benefits outweigh the challenges.

- Respect for the autonomy, context and constraints of each university involved in the collaboration is important.

- University collaboration increases access to educational resources for students and for smaller universities, especially those located in remote areas.

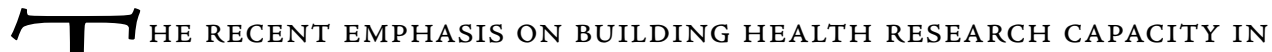 Canada and the significant funding allocated by the Canadian Institutes 1 of Health Research (CIHR) and the Canadian Health Services Research} Foundation (CHSRF) to the development of training centres have spawned innovative collaborations among universities. This paper focuses on the university collaborative models that underpin the four Regional Training Centres overseen by CHSRF to build capacity in applied health and nursing services research.

While significant progress has been made in bringing together faculty members from numerous universities to collaborate on research projects, teaching has tended to be solitary and less responsive to collaborative efforts. Stein and Short $(2001: 418)$ reported in their exploratory study of collaborative degree programs that "faculty, departments, and even institutions have limited experience in working collectively with those who have previously been defined as 'competitors' rather than 'members of the team'. Though it is easy to promote collaboration, it is much more difficult to implement even minimal collaboration, much less a true alliance built upon mutual vision, support, and commitment from all partners."

There is little empirical evidence about the effectiveness of university collaborations in delivering undergraduate and graduate degree programs, and none specifically related to training in applied health services research. Based on our review of the general literature, we summarize the benefits and challenges of university collaborations and strategies to improve program success.

The benefits of inter-university collaborative academic programs include enhancement of curricula and overall program quality; maximization of limited resources and elimination of unnecessary duplication; increased accessibility and flexibility of academic offerings to students; shared decision-making, broader communication and development of trust among inter-university faculty members; increased opportunities for faculty professional development; and a shared vision and cohesive voice for participating universities (Holden-Lund et al. 1991; Offerman 1997; Prideaux et al. 2000; Stein and Short 2001; van Soeren et al. 2000).

On the other hand, challenges to inter-university education-related collaborations include differences in institutional values and culture; rivalry among participating institutions; fear of losing institutional identity and autonomy; establishment 
of an effective program governance structure; unwillingness to challenge the status quo; lack of financial advantage for participating institutions; differences in faculty approach and philosophy; concerns about maintaining program quality; unexpected complexity of communication requiring additional work for faculty and staff and frequent travel to collaborative sites; underestimation of the time required for course development, approval and program administration; reticence to use distance education technologies; and logistics associated with off-site delivery, setting admission standards and fees and meeting accreditation standards (Cragg et al. 2003; Holden-Lund et al. 1991; Short and Stein 1998; Stein and Short 2001; van Soeren et al. 2000).

Strategies to increase the likelihood of success when establishing collaborative academic programs have been identified. Perhaps most important is taking the time to create a culture of collaboration by building consensus about roles and responsibilities, negotiating differences and remaining flexible. Other important activities include meeting the needs of educators across universities, addressing the academic and administrative requirements of all participating universities and establishing and maintaining programs of high academic excellence (Breitborde 1996; Hardy et al. 2004; Prideaux et al. 2000; Short and Stein 1998).

Despite the challenges, there has been encouragement in the United States and Canada to develop collaborative academic programs. For example, collaborative programs in nursing are common in both countries at the undergraduate (Hildebrand and Kirkpatrick 1995; Offerman 1997; Quinless et al. 1997) and graduate levels (Holden-Lund et al. 1991; Hildebrand and Kirkpatrick 1995; Lund et al. 1998; Quinless and Levin 1998; Pohl et al. 2001; Ciesielka et al. 2005; Long 2007).

In the remainder of this paper, we describe the consortium-related features of the CHSRF/CIHR Regional Training Centres (RTCs); outline the benefits and challenges of university collaboration at the graduate level for participating students, faculty and universities; and summarize lessons learned.

\section{The University Collaboration Experience The four RTCs}

In 2001-2002, CHSRF and CIHR committed 10 years of funding for the creation and implementation of three training centres to build capacity in health services and policy research in the Atlantic, Ontario and Western regions of Canada and one training centre in Quebec to focus on development of nursing administration researchers. The training centres are described in detail elsewhere in this journal (Brachman et al. 2008). Each of the RTCs comprises a number of universities that collaborate to deliver the educational offerings at a graduate level. The appendix at the end of the paper summarizes the consortium-related features of the training centres. 
The Atlantic Regional Training Centre (ARTC) in Applied Health Services Research is a collaborative venture among Dalhousie University in Nova Scotia, Memorial University of Newfoundland, the University of New Brunswick and the University of Prince Edward Island. It offers graduate education in applied health services research at both the master's and doctoral levels. Degrees are granted to students by the university in which they enroll, with recognition on their diploma that the degree is part of a collaborative program offered by the four universities.

Centre FERASI (Centre de formation et d'expertise en recherche en administration des services infirmiers/Training and Expertise in Research Applied to Administration of Nursing Services), a consortium of four universities (McGill, Laval, Montreal and Sherbrooke), focuses on the promotion of nursing services research through research training for master's and doctoral students and knowledge transfer. Successful students obtain various degrees in nursing, nursing administration or public health.

The Ontario Training Centre (OTC) in Health Services and Policy Research is a consortium of six Ontario universities (Lakehead, Laurentian, McMaster, Ottawa, Toronto and York) that enables master's and doctoral graduate students from a variety of disciplines (enrolled in any of 42 graduate programs) to obtain training concurrently in health services and policy research. Successful students receive a Diploma in Health Services and Policy Research in addition to their graduate degree (the exception is the University of Toronto, where students receive an equivalent qualification through the Collaborative Graduate Program in Health Services and Policy Research).

The Western Regional Training Centre (WRTC) for Health Services Research is a partnership of four academic departments at three universities (Department of Health Care and Epidemiology at the University of British Columbia [UBC], Department of Community Health Sciences at the University of Manitoba and the Faculty of Nursing and School of Public Health at the University of Alberta) that gives students enrolled in graduate programs the opportunity to take additional training in applied health services research. Students do not receive a separate credential. The WRTC also accepts students from numerous affiliated universities, including Simon Fraser University, University of Victoria, University of Northern BC, UBCOkanagan, University of Winnipeg, Brandon University, University of Saskatchewan and University of Calgary (Brachman et al. 2008).

\section{Consortium features of the RTCs}

CONSORTIUM APPROVAL PROCESS

The ARTC developed a joint master's degree program, and the OTC developed a diploma program. Because these were new programs, all participating universities had to request approval, beginning with their own departments, through to their university boards of governors. Following approval at each university, the consortium approach to awarding a graduate degree or diploma was approved by the respective provincial 
or regional body overseeing graduate education - for ARTC, the Maritime Provinces Higher Education Commission and for OTC, the Ontario Council on Graduate Studies (OCGS). In Ontario, this was the first time that the OCGS had been asked for approval to offer a Type 2 Diploma (a program of study taken concurrently with a graduate degree program) via a consortium approach.

Because Centre FERASI developed new courses that were incorporated into existing graduate programs, new program approval was not required. Similarly, the WRTC courses and seminar series were additional educational offerings in the graduate programs at participating universities; formal approval was not required. For both Centre FERASI and the WRTC, pre-existing university agreements in Quebec and the Western provinces, respectively, enabled students at participating universities to take courses at the other universities, facilitating the offering of RTC courses. In Ontario, students are normally restricted to one course taken at another university; however, to facilitate the OTC diploma program, OCGS lifted this restriction. In addition, the participating universities agreed to waive the Ontario Visiting Graduate Student course fees for these students in anticipation of equitable exchanges of students over the long term.

\section{FORMAL AGREEMENT AMONG CONSORTIUM PARTNERS}

The ARTC and Centre FERASI both have signed agreements among participating universities, while the OTC and WRTC do not. In the ARTC, the deans of graduate studies (or their equivalent) of the four universities signed a memorandum of understanding outlining program regulations, including how administrative differences among universities would be addressed. In Centre FERASI, the Vice Presidents (Research) from each of the four participating universities signed an agreement outlining each university's role, annual financial contribution and allocated number of student positions.

\section{UNIVERSITY PARTICIPATION IN GOVERNANCE}

Each RTC is overseen by an Advisory Board that, in addition to faculty, decisionmaker and student members, includes representation from a number of the participating universities. In the ARTC, the Advisory Board includes the four deans of graduate studies; similarly, in Centre FERASI, the board includes the deans/directors of nursing and researchers from each university. The OTC Advisory Board terms of reference specify membership of at least two senior university administrators. The WRTC board does not include senior university administrators.

\section{COMMUNICATION WITHIN CONSORTIA}

Communication among principal faculty in the participating universities is crucial to building trust and a truly collaborative program. All four training centres use modern 
communication technology (e.g., Web-based instruction, teleconferencing, videoconferencing) to facilitate regular meetings. On-site meetings are held at least once a year to discuss such issues as strategic planning and sustainability. Between meetings, the Program Managers communicate regularly with the principal faculty and site directors or coordinators.

\section{CURRICULUM}

All the RTCs have developed new courses in applied health or nursing services research: eight in the ARTC, five in Centre FERASI, 12 in the OTC and three in the WRTC. Fundamental to each RTC is the shared responsibility across universities for development and course offerings as well as (on a rotating basis) workshops or conferences and Summer/Fall Institutes. If a faculty member who developed a course is not available, training centre faculty at any of the participating universities are invited to offer the course.

\section{ADMINISTRATION OF CONSORTIA}

Each RTC has a senior faculty director/principal with overall responsibility for the centre. As well, each RTC has a site director or coordinator for each participating university to ensure program consistency with the policies and regulations of their respective university, to coordinate student admissions (generally site-specific) and to monitor student progress. Critical to the smooth operation of these university consortia is the full-time Program Manager, who oversees all components of the RTC, including student recruitment, enrolment and orientation; student participation in course offerings, institutes and field placements; and communication with government, regional health authorities, the training centre faculty, Advisory Board, director, site directors, administrative support and graduate program staff. Centre FERASI and the OTC have a number of committees (e.g., Curriculum Committee) with representation from each participating university. In addition, most of the training centres have site-specific admissions committees.

\section{EDUCATIONAL TECHNOLOGY}

Given the considerable distances between the collaborating universities, there is a heavy reliance on educational technology to ensure that students have access to the RTC courses. All ARTC courses are Web-based; Centre FERASI uses videoconferencing; the OTC uses the Web and teleconferencing; and the WRTC uses teleconferencing and some videoconferencing. Yet, there are a number of educational opportunities that are offered on site that require students to travel fair distances and be away from home for periods of time, for example, the week-long institutes. 


\section{Benefits of university collaboration}

STUDENTS

The consortium model broadens the scope of educational benefits for students. In all four RTCs, students are able to enroll in a wider array of courses offered by participating universities. Given that many courses developed by the RTCs are available by distance education, geographic separation of universities is not a barrier. The use of distance education technologies adds flexibility; for example, students can access Web-based course material at their convenience. Students are also exposed to technologies that are rapidly becoming common communication and education tools. RTC students have access to faculty from all the participating universities who teach their courses, and participate in educational offerings such as regional workshops and Summer or Fall Institutes. This approach gives students access to a much broader range of disciplines and experts than traditional programs based within a single university. Students from the participating universities have opportunities to network and learn from one another by taking courses together and by participating in such activities as the regional workshops offered by the ARTC, the Summer Institute offered by the OTC and the Fall Institute offered by the WRTC.

\section{FACULTY}

Participating faculty have an opportunity to collaborate with faculty from various disciplines in other universities. Participation in a consortium focused on education can lead to additional opportunities to collaborate. For example, in the ARTC, principals from all four participating sites successfully competed for funding for an applied health services research project related to assistive technology that also provided financial support for students in the program.

Through the university consortium, faculty are exposed to new learning opportunities through educational offerings such as the annual institutes. For instance, in 2007, the OTC mounted a Summer Institute on regionalization of health services, a concept that has only recently been introduced in Ontario, and one that faculty appreciated learning more about. Through regular meetings with colleagues from other universities, faculty jointly create innovative learning opportunities such as post-training fellowships that are co-sponsored, co-hired and co-supervised by faculty and decisionmakers. The WRTC co-hosted the CIHR Summer Institute in Whistler, BC, in 2004 that brought together 60 graduate students and numerous faculty and decision-makers from across the country. Because many of the RTC offerings rely on distance education technology, faculty have the opportunity to learn more about distance education for use in future course offerings. These experiences may contribute to faculty renewal and retention. 


\section{UNIVERSITIES}

Through participation in a university consortium, universities build program capacity by increasing the number and breadth of educational offerings available to their students. This benefit is especially pertinent to smaller and geographically remote universities that have more limited faculty resources. Given the heavy emphasis of the RTCs on partnerships with policy makers, the universities have an opportunity (which they might not otherwise create for themselves) to develop or strengthen their links with these organizations, forming associations that may lead to future joint endeavours. The RTCs have provided resources and support to facilitate the offering of courses via distance education technology, a strategy that has helped some universities move into this modality more quickly than they might have done otherwise. While universities recognize the increasing importance of interdisciplinary initiatives, they usually do not have the resources to pursue them. With the focus on interdisciplinarity, the RTCs have created a model for future programs. In the case where the RTCs have led to the creation of new graduate programs, one result has been increased revenue for the universities. Evidence of the benefits of the consortium approach to building capacity through the RTCs is apparent by the interest shown by other universities in becoming part of the consortium. For example, Université de Sherbrooke has recently joined the Centre FERASI consortium. With the affiliate-student status in the WRTC, students and faculty from smaller universities across the western provinces have been able to participate in the WRTC program.

\section{Challenges of university collaboration}

In spite of the benefits, academic consortia are complex and present challenges for students, faculty and institutions.

\section{STUDENTS}

While participation in a training centre increases students' exposure to faculty and students at other universities, it can add to the complexity of their graduate education given the increased workload and time required to travel to events such as the Summer/Fall Institutes or regional workshops. There can be an added financial burden because some universities charge additional fees for the RTC offerings. Some students find distance education technology a challenge and claim it distracts from their learning. Participation in RTC offerings such as additional courses and field placements can extend the time students require to complete their degrees.

\section{FACULTY}

A university must ensure that it has sufficient faculty resources to offer its courses. Consequently, when faculty choose to teach RTC courses, this shift in focus from their home university to a university consortium may not be supported by their department 
chairs and deans. The RTC course may compound an already heavy workload with no additional financial compensation. When instructors are not able to teach the training centre course they developed, the responsibility of delivering that course falls on other faculty in the consortium, a situation that can create tension and additional workloads for faculty who want to see the course offered but feel overloaded.

Another considerable challenge is the commitment of time required to manage the program, a commitment that is not always acknowledged or given academic credit. Additional time is required to attend regular meetings of principal faculty within each training centre to ensure smooth operation and to address emerging issues as quickly as possible. In addition, there are regional workshops and Summer or Fall Institutes to attend that often entail substantial travel and demand time away from other work commitments. Training centre participation is sometimes seen as involvement in a "project" rather than an educational endeavour. In this regard, especially for junior faculty, time spent on training centre activities robs time from the scholarly activities traditionally required for promotion and tenure.

\section{UNIVERSITIES}

While some RTCs have succeeded in obtaining external funds for course development, additional funds have been unavailable to cover the costs of teaching. Therefore, universities find themselves burdened with the responsibility of teaching more courses with the same faculty resources. University administrators may perceive that faculty participation in a university consortium program represents time taken away from meeting the university's own needs. Balancing consortium goals with individual institutional autonomy can be a challenge. Universities participating in a consortium may each have different rules and regulations. For example, in the ARTC, grading schemes differed among the four universities. In response, a protocol was developed to convert the grades of all students into a standard grade among the four institutions. Other examples include differences in the name of the degree granted by each university and differences in the dates of midterm breaks, which complicate course attendance. While there is room for some accommodation, the four training centres are committed to respecting the autonomy of the participating universities and to being flexible in developing strategies to achieve a common goal. As summarized by a principal of one training centre: "The essence of the training centre is that it has a common destination, different starting points, common vehicles and different routes."

\section{Lessons Learned}

Perhaps the most important lesson learned by the training centres is the amount of time required to set up and maintain a collaborative program across universities. 
Other universities planning similar initiatives should allow liberal time to create a culture of collaboration, plan the curriculum and secure academic approval at various levels within each participating university and from regional or provincial approval bodies. Substantial time is also needed for regular meetings of the management team and principal faculty, including face-to-face meetings, with their associated travel time.

University representation on the planning and implementation committees for each RTC was instrumental to their success. Each RTC's management and advisory committees include, among others, faculty, university academic administrators and students from some or all of the participating universities. The broad representation ensures that the program is meeting the needs of each university and will help sustain the program after federal government funding ends.

The existing agreements in Quebec and Western Canada that allow students to take courses at other universities facilitated the process of offering collaborative graduate education in applied health and nursing services research. The lifting of the restriction by OCGS that allowed OTC students to take more than one course at another university in Ontario gave the students full access to OTC courses. Universities planning collaborative education programs would benefit from ensuring that such agreements are in place to enhance student accessibility to course offerings at participating universities.

All the training centres use distance technology to facilitate curriculum delivery and administrative processes, including teleconferencing, videoconferencing and Webbased instruction. Although distance technology is essential for collaborative education programs, it must be combined with face-to-face meetings and educational sessions to allow the networking that is essential to collaborative initiatives.

Finally, reciprocal and flexible relationships are essential elements of university collaboration. Each participating university must be willing to assume its share of responsibility for curriculum delivery and program management. The success of a consortium academic program depends on the sustained commitment of all the participating universities to the delivery of a dynamic, high-quality educational experience. The collaboration will work in the long term only if all participating universities are willing to be reciprocal and flexible as needed. At the same time, while working towards a common goal, each university must respect the autonomy, context and constraints of the others.

\section{Conclusion}

University consortia have been successfully developed across Canada to prepare graduate-level applied health and nursing services researchers. The consortia facilitate the sharing of resources and the reduction of duplication while improving access for students. While successful university collaboration entails considerable expenditure 
of time and resources, the benefits for students, faculty and universities outweigh the challenges. Increasingly, university collaboration will be important for the creation of new capacities and resources. The RTC models described in this paper illustrate the complexities of collaboration as well as approaches to facilitating its success.

Correspondence may be directed to: Alba DiCenso, School of Nursing HSC 3N25B, McMaster University, 1200 Main St. West, Hamilton, ON L8N 3Z5; tel.: 905-525-9140, ext. 22277; e-mail: dicensoa@mcmaster.ca.

REFERENCES

Brachman, T., C. Peyton, N. Folch, and M.A. Perez. 2008."Different Roads, Same Destination: Launching Regional Training Centres." Healthcare Policy 3(Sp): 31-45.

Breitborde, M.L. 1996. "Creating Community in the Classroom: Modeling New Basic Skills in Teacher Education." Journal of Teacher Education 47(5): 367-74.

Ciesielka, D., A. Conway, J. Penrose and K. Risco. 2005. "Maximizing Resources: The S.H.A.R.E. Model of Collaboration." Nursing Education Perspectives 26(4): 224-26.

Cragg, C.E., S. Doucette and J. Humbert. 2003. “Ten Universities, One Program: Successful Collaboration to Educate Nurse Practitioners." Nurse Educator 28(5): 227-31.

Hardy, E., M. Gartland, N. DeBasio, W. Bassett, L. Warmbrodt and M. Tansey. 2004.

"Collaborative Graduate Education: Executive Nurse Practice and Health Care Leadership." Nursing Leadership Forum 8(4): 123-27.

Hildebrand, S. and S. Kirkpatrick. 1995. "Beyond the Niceties of Networking: Schools Shrug Off Traditional Boundaries for Better Education and the Future of the Profession." Nurse Educator 20(2): 15-16.

Holden-Lund, C., E. Tate and B. Hyde-Robertson. 1991. “Consortium Model for Master's Education in Nursing." Nurse Educator 16(5): 13-17.

Long, K.A. 2007. “Nursing PhD Consortia: A Model for Maximizing Scarce Resources.” Journal of Professional Nursing 23(5): 262-66.

Lund, C., E. Tate and B. Hyde-Robertson. 1998. "Benefits and Challenges of a Graduate Nursing Consortium." Nurse Educator 23(6): 13-16.

Offerman, M.J. 1997. “Collaborative Degree Programs: A Facilitational Model." Continuing Higher Education Review 61 (Spring): 28-55.

Pohl, J.M., A.C. Bostrom, G. Talarczyk and S. Cavanagh. 2001. “Development of an Academic Consortium for Nurse-Managed Primary Care." Nursing and Health Care Perspectives 22(6): 30813.

Prideaux, D., J. Teubner, A. Sefton, M. Field, J. Gordon and D. Price. 2000."The Consortium of Graduate Medical Schools in Australia: Formal and Informal Collaboration in Medical Education." Medical Education 34: 449-54.

Quinless, F.W., N. Elliot and E. Saiff. 1997."Partnerships in Higher Education: A Model for Joint Degree Nursing Programs." Journal of Professional Nursing 13(5): 300-6.

Quinless, F.W. and R.F. Levin. 1998. "Northern New Jersey Nursing Education Consortium: A Partnership for Graduate Nursing Education." Journal of Professional Nursing 14(4): 220-4. 


\section{Alba DiCenso et al.}

Short, P.M. and R.B. Stein. 1998. "Collaborative Doctoral Education: Overcoming Barriers, Building Coalition and Achieving Results." NCA Quarterly 72(4): 457-61.

Stein, R.B. and P.M. Short. 2001. “Collaboration in Delivering Higher Education Programs: Barriers and Challenges." Review of Higher Education 24(4): 417-35.

van Soeren, M.H., M.-A. Andrusyszyn, H.K. Spence Laschinger, D. Goldenberg and A. DiCenso. 2000. "Consortium Approach for Nurse Practitioner Education." Journal of Advanced Nursing 32(4): 825-33. 


\begin{tabular}{|c|c|c|c|}
\hline 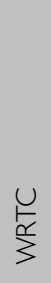 & 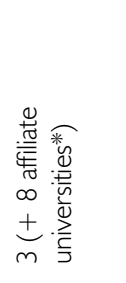 & 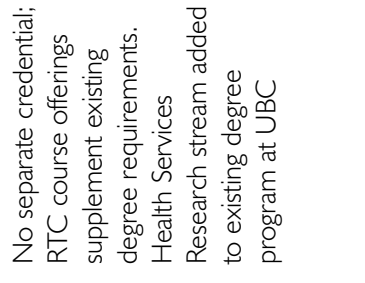 & 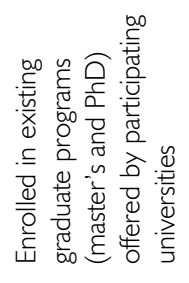 \\
\hline$\stackrel{\cup}{\circ}$ & 0 & 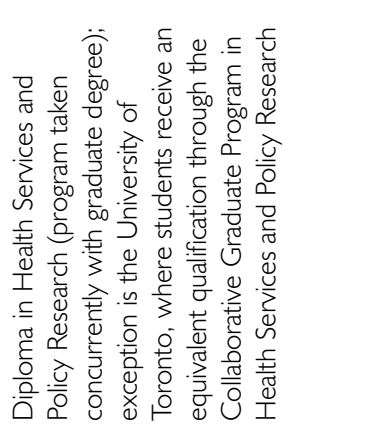 & 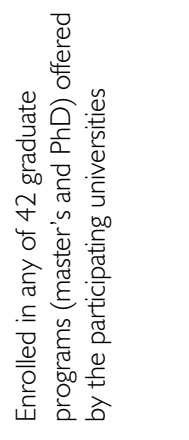 \\
\hline 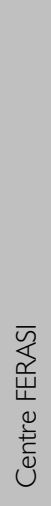 & $\nabla$ & 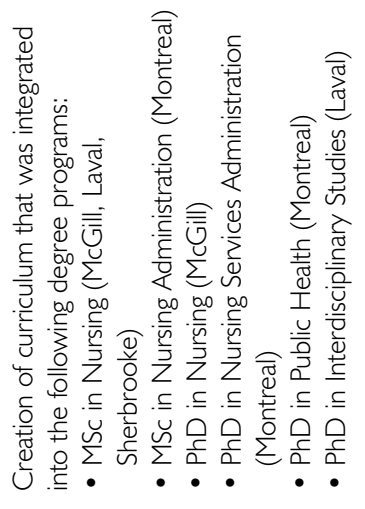 & 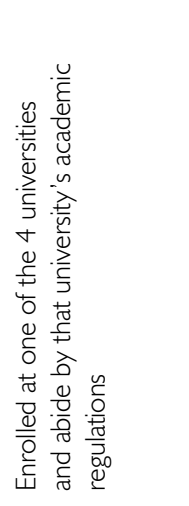 \\
\hline$\frac{U}{\frac{v}{\alpha}}$ & $\nabla$ & 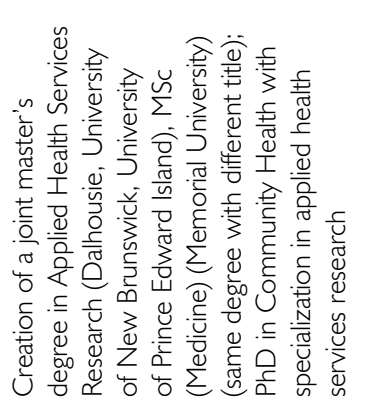 & 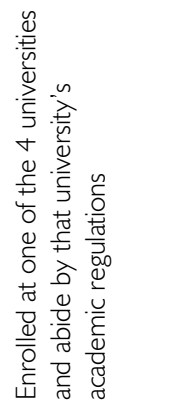 \\
\hline & 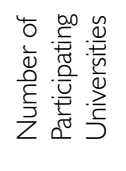 & 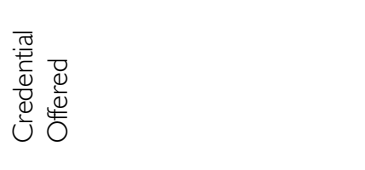 & $\begin{array}{l}\frac{n}{0} \\
\frac{\mathbb{d}}{0} \\
\text { 总 }\end{array}$ \\
\hline
\end{tabular}


Alba DiCenso et al.

\begin{tabular}{|c|c|c|c|c|}
\hline$\frac{0}{3}$ & 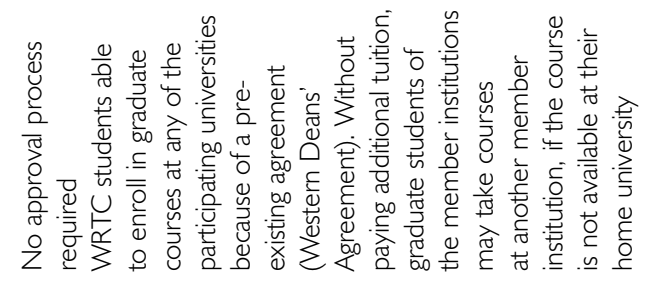 & 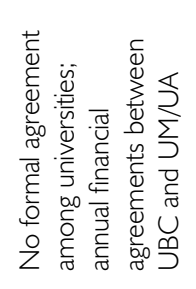 & 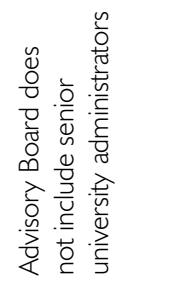 & 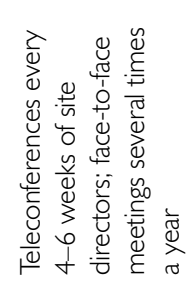 \\
\hline 5 & 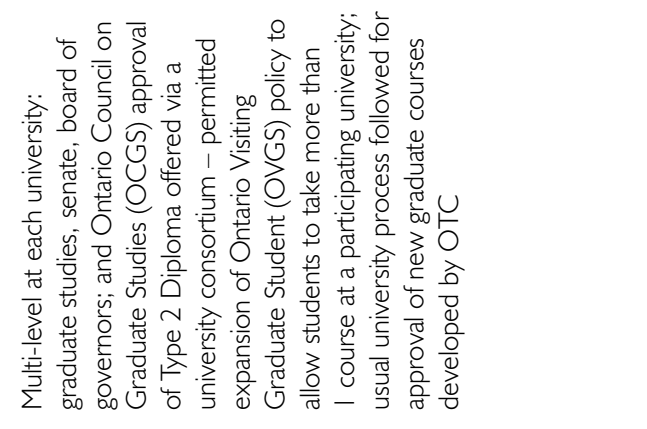 & 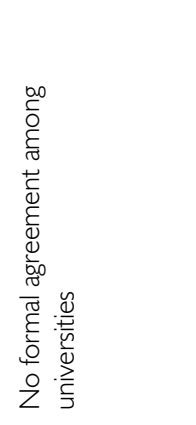 & 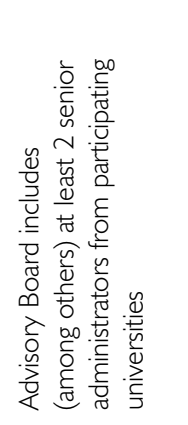 & 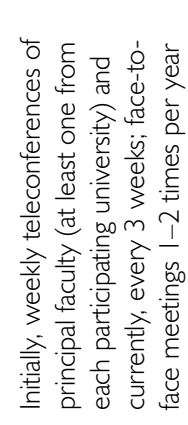 \\
\hline 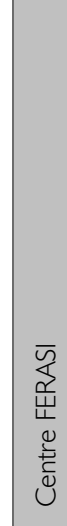 & 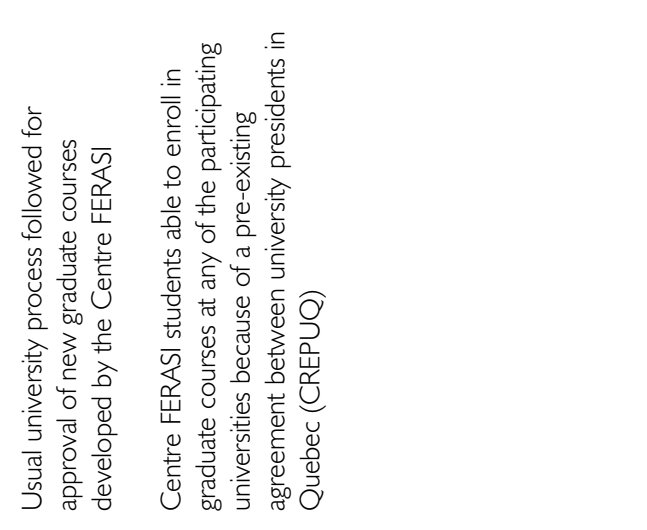 & 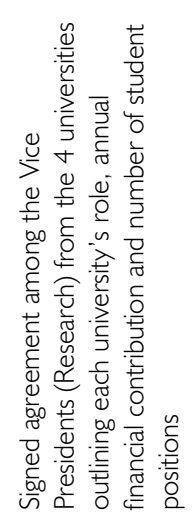 & 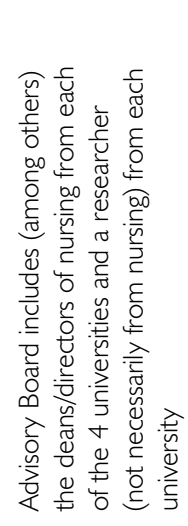 & 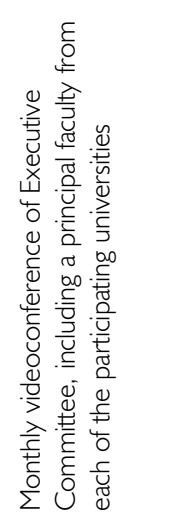 \\
\hline$\frac{b}{\frac{v e}{x}}$ & 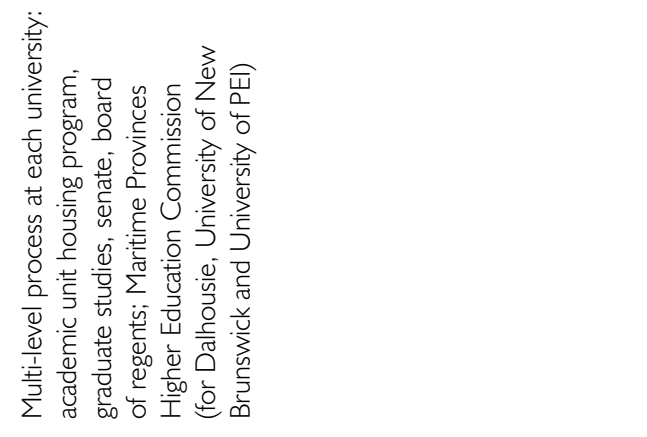 & 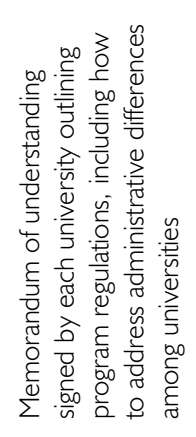 & 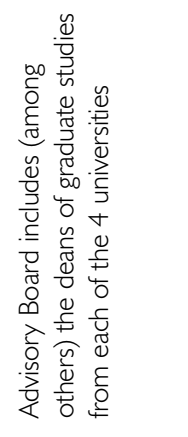 & 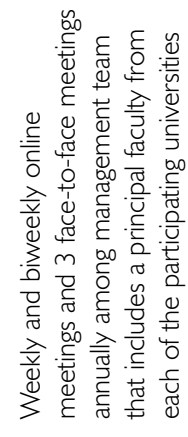 \\
\hline & 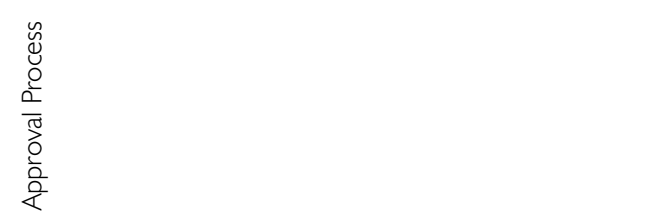 & 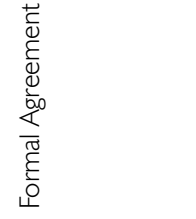 & 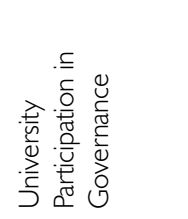 & 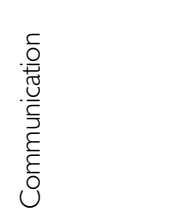 \\
\hline
\end{tabular}




\begin{tabular}{|c|c|c|c|}
\hline$\frac{U}{\frac{u}{3}}$ & 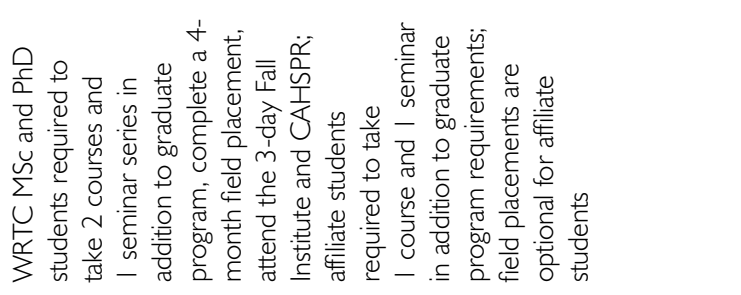 & 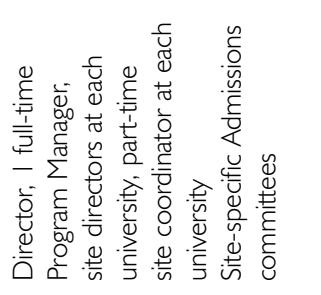 & 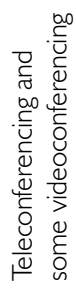 \\
\hline 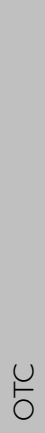 & 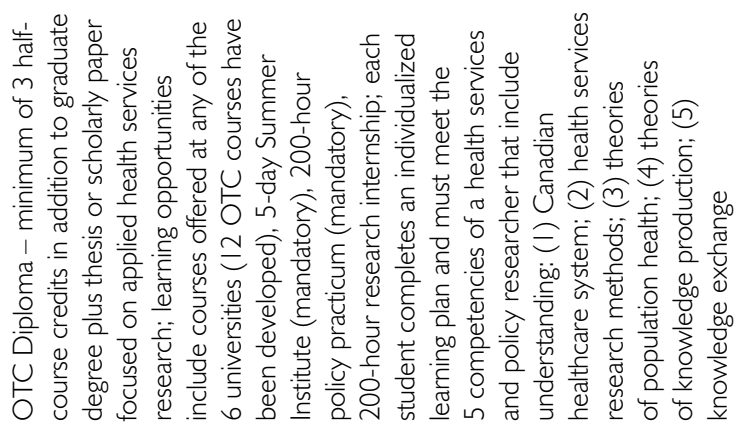 & 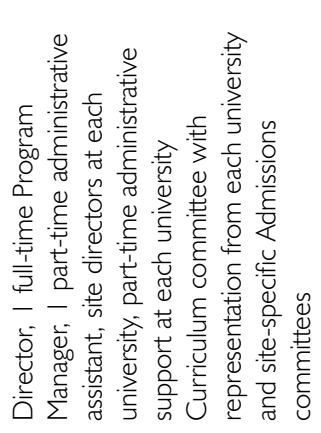 & 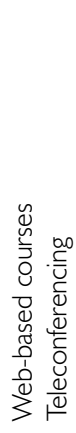 \\
\hline 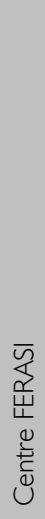 & 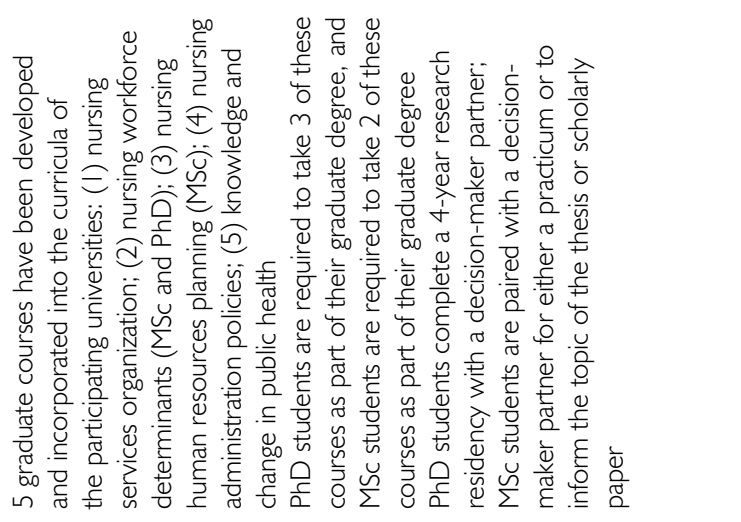 & 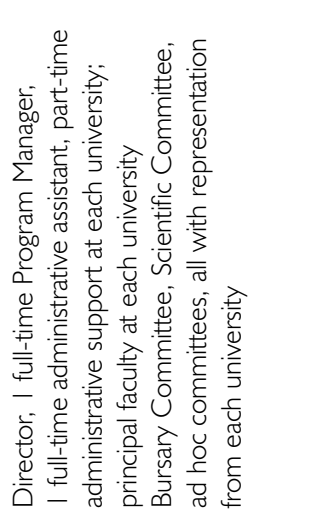 & 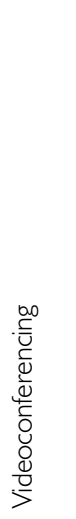 \\
\hline$\frac{U}{\frac{u}{<}}$ & 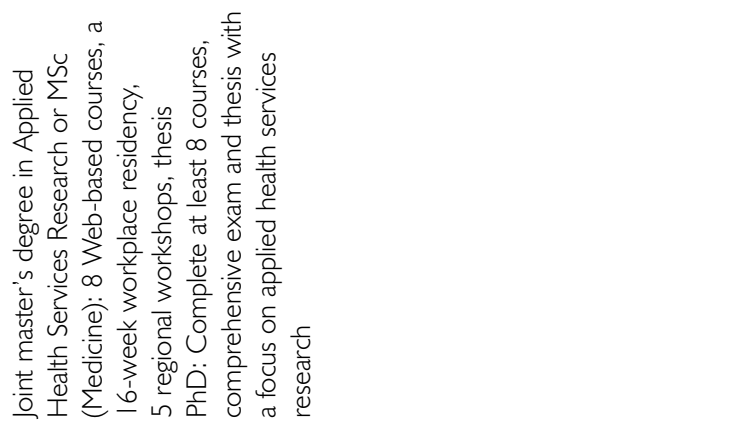 & 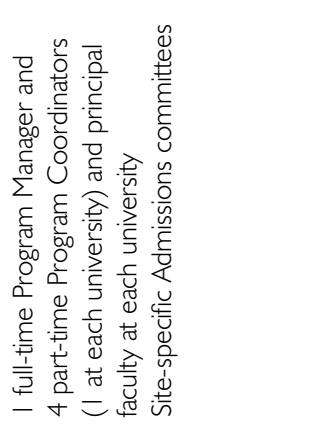 & 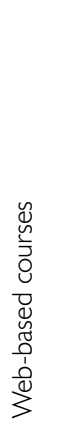 \\
\hline & 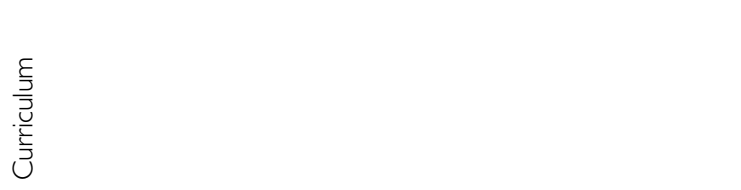 & 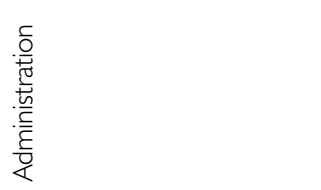 & 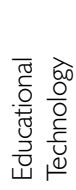 \\
\hline
\end{tabular}

